\title{
Semen Characteristics and Behavior of Graz- ing Bulls as Influenced by Shade
}

\author{
S.W. COLEMAN, D.C. MEYERHOEFFER AND F.P. HORN
}

\begin{abstract}
The efficiency of shades to provide bulls relief from heat stress was studied during the summers of 1977 and 1978 . The shades were constructed from steel pipe with expanded metal roof covered with baled straw. Ambient and blackbulk temperatures were more variable in 1977 than in 1978. No consistent influence of shade availability was observed in behavior of the bulls, though during 1978 , less time was spent grazing by bulls with access to shade. During both years, standing time was greater $(P<.10)$ by bulls without access to shade. Bulls made little use of the shades in August and September. In 1977, semen motility, movement rate, and percentage live sperm cells were greater $(P<.10)$ from bulls provided shade. Bulls without shade showed a trend for higher numbers of aged acrosomes and abnormal sperm cells. General semen quality was lower in 1978, but no consistent effect of shade was noted, except that abnormal sperm cells were lower from bulls with access to shade. During both years, semen motility was decreased and percentage of abnormal sperm cells was increased 2- to 3-weeks after blackbulb temperatures approached $45^{\circ} \mathrm{C}$ for several consecutive days.
\end{abstract}

Benefits of shade in terms of improved performance have been shown by Mcllvain and Shoop (1971) on Oklahoma range and by Pontif et al. (1974) on Louisiana pastures. They also observed that humidity may be as important or more so than temperature. However, valuable nutrients from feces are deposited around the shaded areas, rather than scattered over the pastures. Further, cattle may tend to reduce total grazing time and hence reduce total dry matter intake, limiting performance (Warwick and Bond 1966). Lowered breeding efficiency has been demonstrated for both sexes during seasons with high temperatures (Erb and Waldo 1952, Stott 1961). After 2-3 weeks, semen from bulls subjected to high temperatures $\left(35^{\circ} \mathrm{C}\right.$ for 8 hours and $31^{\circ} \mathrm{C}$ for remaining 16 hours/day) in environmental chambers was less motile and contained more abnormal cells than that from controls (Meyerhoeffer et al. 1976). After temperatures were reduced, 8 weeks were required for the bulls to recover. Also, Bond and McDowell (1972) noted that females became anestrus when exposed to $38^{\circ} \mathrm{C}$ and $60 \%$ humidity for 56 days and that some winter-acclimated heifers stopped cycling when exposed to $32^{\circ} \mathrm{C}$. Temperatures above $38^{\circ} \mathrm{C}$ are occasionally recorded in the Southern Great Plains and more frequently in the range areas of Texas, New Mexico, and Arizona.

This research was initiated to determine if shade was effective in alleviating the stress of summer temperatures and its influence on performance, behavior, and semen quality of bulls.

\section{Methods}

During 2 spring and summer grazing seasons, four pastures $(0.4$ ha each) of bermudagrass (Cynodon dactylon (L.) Pers.) were grazed by yearling Angus bulls. One bull per pasture was used in 1977 and 3 bulls per pasture were used in 1978. Pastures were fertilized both years with $54.5 \mathrm{~kg} \mathrm{~N} /$ ha in early spring and again in mid-July. Irrigation was used to maintain forage growth on por-

Authors are research animal nutritionist, research animal scientist, and research animal nutritionist, respectively, Livestock and Forage Research Laboratory, USDAARS, P.O. Box 1199, El Reno, Okla. 73036. This research was a cooperative effort between the USDA-ARS, Southern Region, and Oklahoma State University, Stillwater.

Manuscript received April 19, 1983. tions of each pasture in 1977. To provide adequate forage for the additional animals in 1978, the entire pastures were irrigated weekly except when rain had fallen during the previous week. A gross estimate of forage availability was obtained by clipping four $1 / 2-\mathrm{M}^{2}$ areas per pasture. The clipped forage was weighed after oven drying at $65^{\circ} \mathrm{C}$. Two pastures each year contained artificial shades ( $3.8 \mathrm{~m}$ square and $4.7 \mathrm{~m}$ high) constructed from steel pipe and covered with baled straw. Shades were open on all sides for ventilation.

The bulls were rotated among pastures at 3- (1977) or 4- (1978) week intervals in a latin square pattern so that each bull grazed all pastures at some time during the season. Shades were moved at the same time to maintain bulls on their assigned shade treatment. Two weeks after each rotation, bulls were observed to determine effect of shade on behavior. Observations were made during 1 24-hour period every 3 weeks in 1977 and during 2 16-hour periods (6 AM to $10 \mathrm{PM}$ ) on 2 consecutive days every 4 weeks during 1978. Data recorded included whether each bull was standing, lying, walking, or grazing at the end of each interval of 15 minutes. The time spent under the shade was recorded for bulls assigned to the shade treatments. Ambient and blackbulb temperatures in and out of shade were recorded every 2-3 hours daily from $8 \mathrm{AM}$ to $5 \mathrm{PM}$. Daily temperature extremes were averaged for each week and standard errors calculated. Also, continuous ambient temperature and humidity recordings were made with a hygrothermograph in covered weather stations in the center of the pasture area.

The bulls were electro-ejaculated each week for semen evaluation and weighed at 3-week intervals. Semen traits evaluated included sperm number, motility, estimated rate of movement (scale 1-5), and percentage live and percentage abnormal cells. Cell and acrosomal morphology was quantitated on $100 \mathrm{sperm}$ per stained smear as described by Wells et al. (1971) for each ejaculate in 1977 only.

All response variables were statistically analyzed using a splitplot analysis of variance (Gill and Hafs, 1971) for repeated measurements on the same animals. Semen traits were normalized for date within year and pooled across years. Where significant shade $X$ year $X$ date interactions were found, separate analyses were conducted within each year. Weight gain and grazing behavior were analyzed separately within each year.

\section{Results}

The average daily minimum humidity occurred near the time of peak ambient temperature and was, in general, very low both years (Fig. 1 and Fig. 2). Ambient temperatures (average daily maximum) in $1977\left(32^{\circ} \mathrm{C}\right)$ were similar to those in $1978\left(33^{\circ} \mathrm{C}\right)$ though weekly patterns and variation differed $(P<.05)$. During both years, temperatures were above normal and precipitation below normal, except for August, 1977 when precipitation was above normal and August, 1978 when the average temperature was essentially normal (Table 1). Blackbulb temperatures, accepted as a measure of solar radiation effects and heat load, fluctuated through the grazing season and a significant $(P<.05)$ interaction between the effects of year and date was noted. Absorption of solar radiation was suggested as an important factor in aggravating high temperature stress (Warwick and Bond 1966). Maximum daily blackbulb 

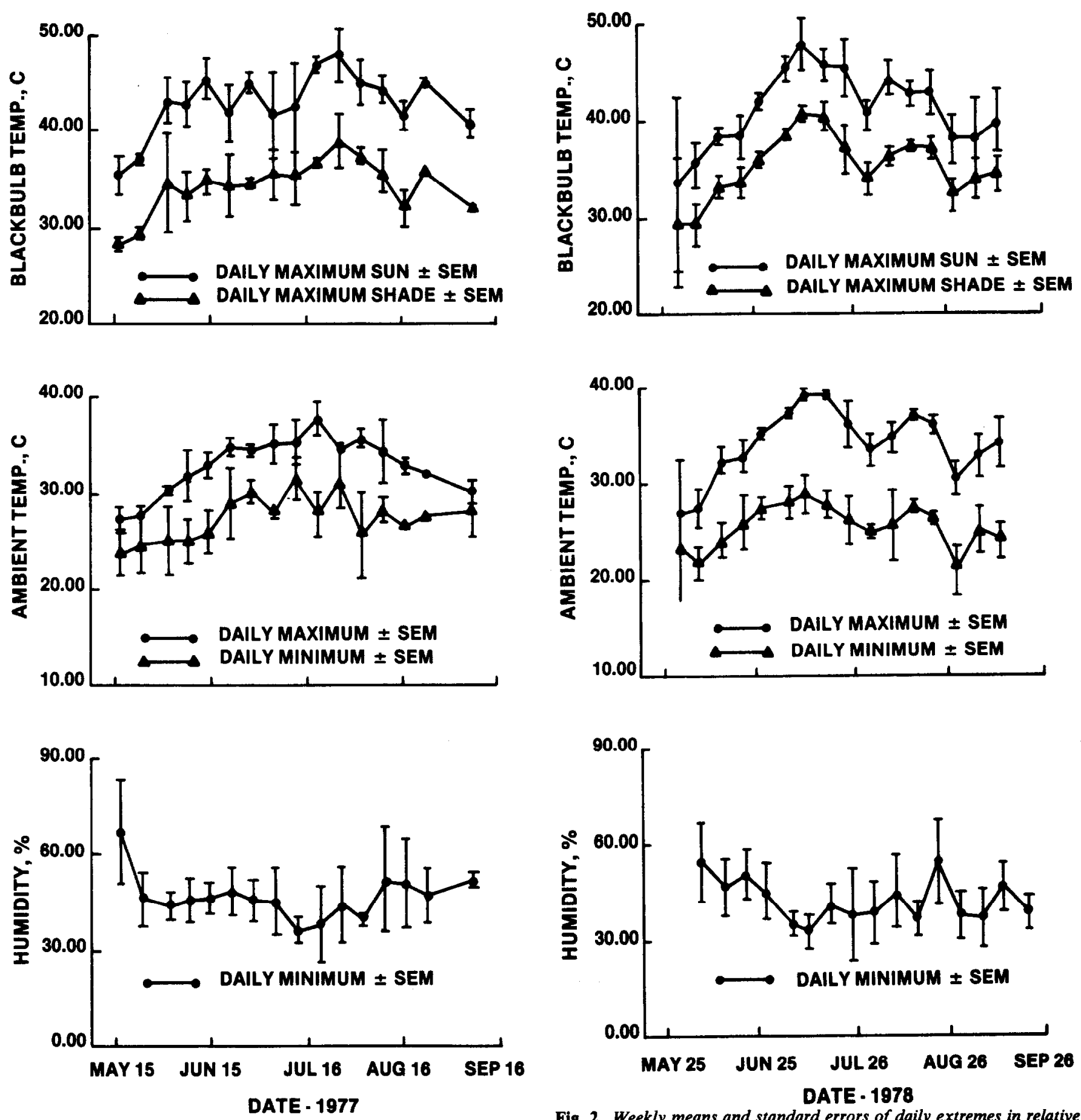

Fig. 1. Weekly means and standard errors of daily extremes in relative humidity and in ambient and blackbulb temperatures, during 1977.

temperature averaged $44^{\circ} \mathrm{C}$ in the sun and $34^{\circ} \mathrm{C}$ in the shade during 1977 , and $41 \mathrm{c}$ in the sun and $35^{\circ} \mathrm{C}$ in the shade in 1978 . The difference between shade and sun was greater in 1977 and certainly both were more variable within each week than in 1978. The Angus bulls used were no doubt very sensitive to the heat load generated by solar radiation and the alleviation of part of the load by the shades. Maximum daily ambient temperature was consistently above $35^{\circ} \mathrm{C}$ for 3 weeks beginning about June 25,1978 . Weekly means of maximum ambient temperature were much more variable in 1977 than in 1978.

Weight gains of bulls did not differ due to shade $(P>.10)$ in either year, but were higher in 1977 than in 1978 (Table 2). The bulls in

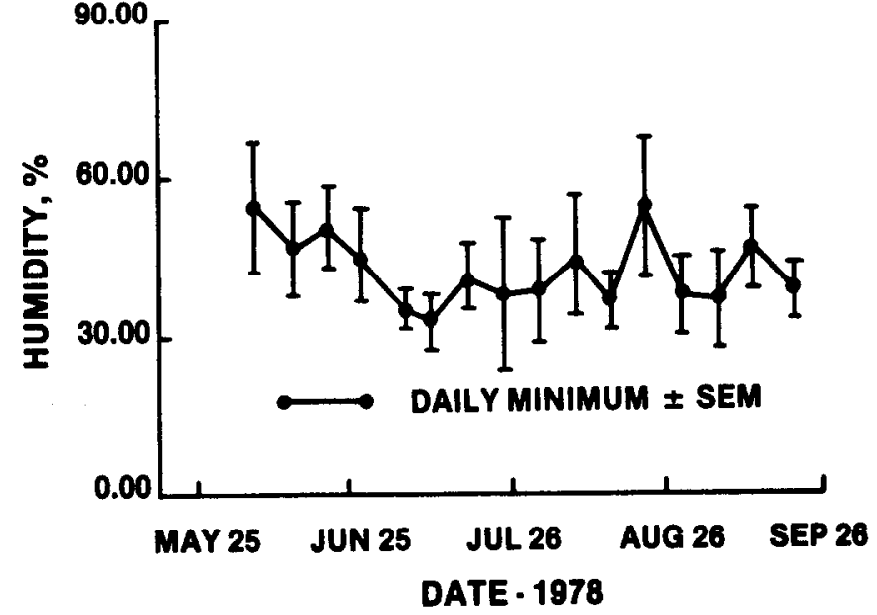

Fig. 2. Weekly means and standard errors of daily extremes in relative humidity and in ambient and blackbulb temperatures, during 1978.

Table 1. Climatological data (monthly averages).

\begin{tabular}{|c|c|c|c|c|c|}
\hline \multirow[b]{2}{*}{ Date } & \multirow{2}{*}{$\begin{array}{c}\text { Wind speed } \\
\text { MPH }\end{array}$} & \multicolumn{2}{|c|}{ Temperature, $\mathrm{C}$} & \multicolumn{2}{|c|}{ Precipitation, $\mathrm{cm}$} \\
\hline & & Actual & Normal & Actual & Normal \\
\hline $\begin{array}{c}1977 \\
\text { June } \\
\text { July } \\
\text { Aug. } \\
\text { Sept. }\end{array}$ & $\begin{array}{l}12.6 \\
11.1 \\
11.0 \\
12.1\end{array}$ & $\begin{array}{l}26.6 \\
29.1 \\
27.7 \\
25.2\end{array}$ & $\begin{array}{l}25.1 \\
27.6 \\
27.4 \\
22.7\end{array}$ & $\begin{array}{r}7.3 \\
4.9 \\
12.5 \\
2.8\end{array}$ & $\begin{array}{l}9.8 \\
6.6 \\
6.2 \\
7.1\end{array}$ \\
\hline $\begin{array}{c}1978 \\
\text { June } \\
\text { July } \\
\text { Aug. } \\
\text { Sept. }\end{array}$ & $\begin{array}{l}11.7 \\
10.8 \\
10.3 \\
10.3\end{array}$ & $\begin{array}{l}25.8 \\
30.4 \\
27.3 \\
25.3\end{array}$ & $\begin{array}{l}25.1 \\
27.6 \\
27.4 \\
22.7\end{array}$ & $\begin{array}{l}6.9 \\
2.7 \\
2.7 \\
6.8\end{array}$ & $\begin{array}{l}9.8 \\
6.6 \\
6.2 \\
7.1\end{array}$ \\
\hline
\end{tabular}


Table 2. Influence of shade availabillty on daily activities."

\begin{tabular}{lccccc}
\hline \hline & \multicolumn{2}{c}{1977} & & \multicolumn{2}{c}{1978} \\
\cline { 2 - 3 } \cline { 5 - 6 } Activity & Shade & Sun & Shade & Sun \\
\hline Number of bulls & 2 & 2 & 6 & 6 \\
Initial wt, $\mathrm{kg}$ & 340 & 345 & 422 & 404 \\
Weight gain, kg/day & .45 & .41 & .10 & .15 \\
Grazing, hours & 6.3 & 5.9 & $6.1^{\mathrm{b}}$ & 6.3 \\
Standing, hours & $5.3^{\mathrm{b}}$ & 6.2 & & $4.7^{\mathrm{c}}$ & 5.0 \\
Lying, hours & 12.1 & 11.6 & $5.2^{\mathrm{c}}$ & 4.4 \\
Walking, hours & .4 & .3 & .2 & .3 \\
Time spent in shade, hours & 3.5 & - & 1.8 & - \\
\hline
\end{tabular}

Total of 24 hours in 1977; 16 hours in 1978.

b Values for shade and sun within a year were different $(P<10)$

Values for shade and sun within a year were different $(\boldsymbol{P}<.05)$.

1978 were larger at the onset of the trial than those in 1977 and may have been nearly mature, thus exhibiting less growth (Table 2). McIlvain and Shoop (1971) observed that steers gained $9 \mathrm{~kg} / \mathrm{head}$ more over the season if they had access to shade during hot summer days. Cartwright (1955) found that cattle from temperate zones began to show signs of heat stress at about $30^{\circ} \mathrm{C}$. However, McIlvain and Shoop (1971) noted that under Southern Plains conditions, relative humidity was more influential upon steer gains than temperature. They found that high humidity in the presence of high temperatures severely lowered steer gains during a 20 -year period. In central Oklahoma, the effects of relative humdity are difficult to assess since the maximum (near $100 \%$ each day) occurs during the night when temperatures are moderate. Minimum relative humidity seldom exceeded $65 \%$ during the study period. The highest monthly noon-day average occurred in June, 1978 , and was $62 \%$.

\section{Behavior}

There were no clear effects of shade on time spent grazing during the limited numbers of observations made (Table 2). It has been suggested (Warwick and Bond 1966) that during hot weather, cattle sacrifice grazing time in order to utilize shade. However, in
1977, more hours were spent grazing by bulls which had access to shade. Bulls spent less $(P<10)$ time grazing in 1978 when shade was available, but gains were not different due to shade. Kropp et al. (1973) observed grazing times by cows on native range at this research location which were similar to those of the bulls in the current study. Mcllvain and Shoop (1971) noted that cattle on range tend to use all the natural shade available and frequently utilize shade trees as much as $1,600 \mathrm{~m}$ from the water source. No natural shade was available in the current experiment.

During both years, bulls spent less time in the shade during the first observation period in May (1977) and June (1978) (Table 3). Peak use occurred in June (1977) and July (1978). During August and September 1978, very little use of the shades occurred, even though temperatures in August were only $4^{\circ} \mathrm{C}$ less than in July. In both years, bulls with access to shade spent less time standing $(P<.10)$ than those without shade. In 1978, this extra time was used lying $(P<.05)$, and the difference occurred during the July 27 observation. There appeared little relationship between temperature on observation days and behavior (Table 3 ).

Grazing time was greater $(P<1)$ following the first observation period each year. In 1977, forage dry matter yield also increased as the season progressed. However, green forage available per unit area, and thus forage quality, was probably depressed, although these measurements were not made. A small area in the center of each pasture was irrigated in 1977 and the entire pasture was irrigated weekly in 1978, unless it had rained during the previous week. During 1977, the grazing pressure of 1 animal per pasture was less than adequate. Green, actively growing forage was, in general, maintained where the irrigation was provided. The forage outside the irrigated area was $12-24 \mathrm{~cm}$ tall, dormant, and quite stemmy. Nevertheless, the bulls made better gains in 1977 than in 1978. Stating whether the weather, lowered stocking rate, or initial weight of the bulls were contributing factors would only be conjecture. From observation, even though animals had a greater amount of forage available in 1977, it appeared that more green forage was available in 1978 . However, lack of slectivity by the animals in 1978 due to decreased availability of forage could be an overriding factor.

Table 3. Effect of shade and date on bull activity.

\begin{tabular}{|c|c|c|c|c|c|c|c|c|}
\hline \multirow[b]{2}{*}{ Date } & \multirow[b]{2}{*}{ Treatment } & \multirow[b]{2}{*}{ Graze } & \multirow[b]{2}{*}{ Stand } & \multirow[b]{2}{*}{ Lying } & \multirow[b]{2}{*}{ Walk } & \multirow{2}{*}{$\begin{array}{c}\text { In } \\
\text { shade }\end{array}$} & \multicolumn{2}{|c|}{ High temperature } \\
\hline & & & & & & & Ambient & $\overline{B B}^{\mathrm{a}}$ \\
\hline & & & & Irs- & & & & \\
\hline \multicolumn{9}{|l|}{1977} \\
\hline \multirow[t]{2}{*}{ May 24} & Shade & $5.4^{\circ}$ & 5.5 & $13.1^{f}$ & .0 & .6 & 27.0 & 29.0 \\
\hline & Sun & $4.4^{e}$ & 5.4 & $13.7^{f}$ & .5 & - & 27.0 & 36.5 \\
\hline \multirow[t]{2}{*}{ June 16} & Shade & $6.4^{t}$ & 4.9 & $12.1^{f}$ & .6 & 5.2 & 32.0 & 34.0 \\
\hline & Sun & $5.4^{t}$ & 5.9 & $12.2^{f}$ & .5 & - & 32.0 & 43.0 \\
\hline \multirow[t]{2}{*}{ July 6} & Shade & $6.6^{1}$ & 6.1 & $10.6^{\circ}$ & .6 & 4.6 & & \\
\hline & Sun & $7.8^{f}$ & 5.5 & $10.5^{\circ}$ & .2 & - & $34.4^{8}$ & \\
\hline \multirow[t]{2}{*}{ July 27} & Shade & $6.7^{f}$ & 4.6 & $12.4^{f}$ & .2 & 3.5 & & \\
\hline & Sun & $6.1^{f}$ & 8.0 & $9.9^{\circ}$ & .0 & - & $27.0^{\mathrm{h}}$ & \\
\hline \multicolumn{9}{|l|}{1978} \\
\hline \multirow[t]{2}{*}{ June $15-16$} & Shade & $5.5^{\mathrm{c}}$ & $5.7^{d}$ & 4.8 & .1 & .3 & 32.2 & 34.8 \\
\hline & Sun & $5.1^{c}$ & $5.6^{\mathrm{d}}$ & 5.2 & .2 & - & 33.6 & 39.4 \\
\hline \multirow[t]{2}{*}{ July $13-14$} & Shade & $6.1^{\text {ed }}$ & $4.5^{\text {ed }}$ & 5.3 & .3 & 4.5 & 39.0 & 41.0 \\
\hline & Sun & $6.8^{\mathrm{cd}}$ & $4.9^{\text {cd }}$ & 4.0 & .3 & - & 39.0 & 48.5 \\
\hline \multirow[t]{2}{*}{ August $10-11$} & Shade & $5.8^{d}$ & $5.0^{\mathrm{cd}}$ & 5.0 & .2 & 1.3 & 34.0 & 37.0 \\
\hline & Sun & $6.3^{d}$ & $6.1^{\text {cd }}$ & 3.6 & .3 & - & 36.0 & 44.0 \\
\hline \multirow[t]{2}{*}{ Sept $7-8$} & Shade & $6.9^{d}$ & $3.7^{\mathrm{c}}$ & 5.4 & .1 & 1.0 & 30.5 & 33.0 \\
\hline & Sun & $7.0^{d}$ & $4.0^{c}$ & 5.0 & .2 & - & 31.5 & 36.0 \\
\hline
\end{tabular}

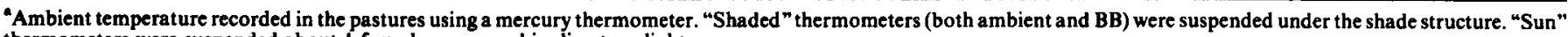
thermometers were suspended about $1.5 \mathrm{~m}$ above ground in direct sunlight.

BB = Blackbulb.

Values in the same column with year with different superscripts differ $(P<10)$.

'Values in the same column within year with different superscripts differ $(P<.05)$.

Other temperatures were not available for this date.

${ }^{\mathrm{h}}$ Due to rain other temperatures were not recorded. 


\section{Semen Quality}

The quality of the semen from bulls without shade was adversely affected during 1977 when compared with semen from bulls with access to shade (Table 4). Motility (Fig. 3) and estimated movement rate, both estimates of sperm activity, were greater $(P<.10)$

Table 4. Effect of shade on semen characteristics of bulls.

\begin{tabular}{|c|c|c|c|c|}
\hline Characteristic & Shade & Sun & $\mathrm{SE}^{*}$ & Probability $^{\mathrm{b}}$ \\
\hline \multicolumn{5}{|l|}{1977} \\
\hline Sperm motility, \% & 84.2 & 67.1 & 7.7 & .09 \\
\hline Rate $^{c}$ & 4.5 & 3.5 & .4 & .07 \\
\hline Sperm number $/ \mathrm{cc} \times 10^{9}$ & 35.8 & 25.3 & 5.5 & .11 \\
\hline Live cells, $\%$ & 82.1 & 68.3 & 1.8 & .01 \\
\hline Abnormal cells, $\%$ & 14.1 & 19.7 & 3.5 & .14 \\
\hline \multicolumn{5}{|l|}{1978} \\
\hline Sperm motility, \% & 69.1 & 66.4 & 2.9 & .59 \\
\hline Rate $^{\mathrm{c}}$ & 3.6 & 3.6 & .2 & .95 \\
\hline Sperm number $/ \mathrm{cc} \times 10^{9}$ & 51.5 & 75.3 & 9.9 & .03 \\
\hline Abnormal cells, $\%$ & 14.9 & 17.9 & 1.3 & .09 \\
\hline
\end{tabular}

"Standard error of the mean.

${ }^{6}$ Probability that differences are due to chance rather than treatment.

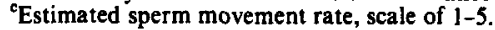

when bulls had access to shade. Further, percentage live cells was greater $(P \leq .01)$ and percentage abnormal cells (both years) were lower $(P \leq .14)$ from shaded bulls. Poor semen characteristics have also been seen in other species (Dutt and Simpson, 1957; Wetteman et al. 1976) due to heat stress. Sperm cell number was highly variable within treatment, although a trend for greater number of cells occurred with shaded bulls. Accompanying the reduction in
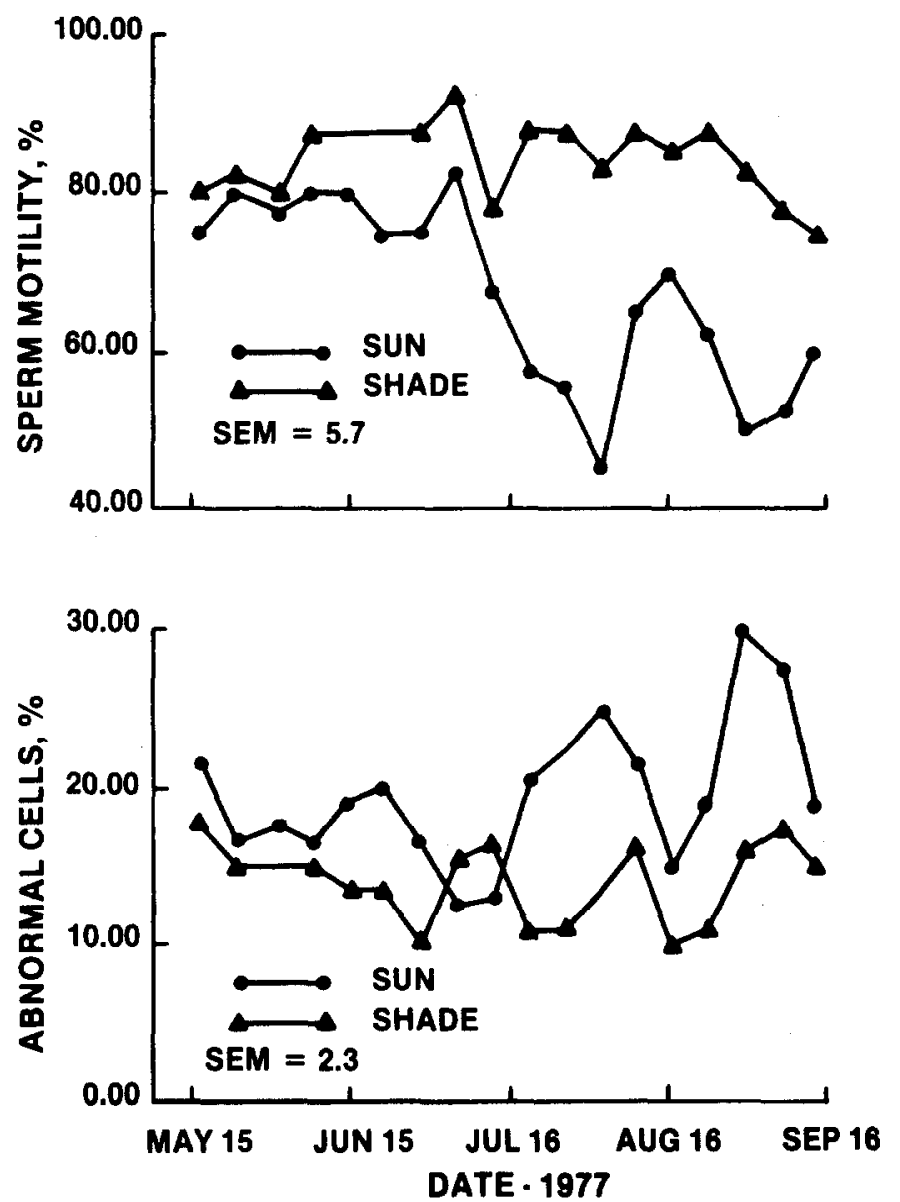

Fig. 3. Weekly changes in semen motility and percentage of abnormal cells during 1977. SEM is the standard error of the mean. motility and percentage live cells was a change in morphological characteristics of the sperm of bulls without access to shade (Table 5). Microscopic evaluation revealed that more sperm cells were

Table 5. Effect of shade on some semen characteristics (1977).

\begin{tabular}{lrrrc}
\hline \hline Characteristic & Shade & Sun & SE $^{\mathrm{a}}$ & Probability $^{\mathrm{b}}$ \\
\hline & & \multicolumn{1}{c}{$\%$} & & \\
Normal $^{\mathrm{c}}$ & 84.3 & 68.6 & 8.8 & .13 \\
Total aged $^{\mathrm{d}}$ & 6.0 & 11.3 & 3.9 & .19 \\
Normal non-aged $^{\text {Normal aged }}$ & 81.1 & 63.5 & 9.4 & .12 \\
Abnormal non-aged & 3.1 & 5.0 & 1.0 & .12 \\
Abnormal aged & 13.2 & 25.4 & 6.5 & .12 \\
& 2.9 & 6.4 & 3.2 & .26 \\
\hline
\end{tabular}

Standard error of the mean.

brobability that differences are due to chance rather than treatment.

'Normal refers to sperm cells.

${ }^{d}$ Aged refers to acrosomes.

abnormal $(P=13)$ and had aged acrosomes $(P=.19)$ when bulls did not have access to shade. The predominant characteristic was a $50 \%$ increase in the number of aged acrosomes and abnormal cells from bulls without access to shade when compared with shaded bulls. Acrosome anomalies interfere with the ability of the sperm to attach to the ovum during fertilization. Similar types of changes were seen when bulls (Meyerhoffer et al. 1976) and boars (Wettemann et al. 1976) were subjected to heat stress produced by prolonged periods in heat chambers.

In 1978 , all bulls produced relatively poor quality semen with less than $70 \%$ motility and an estimated movement rate of less than four (scale 1-5) (Fig. 4, Table 4). Neither of these parameters were
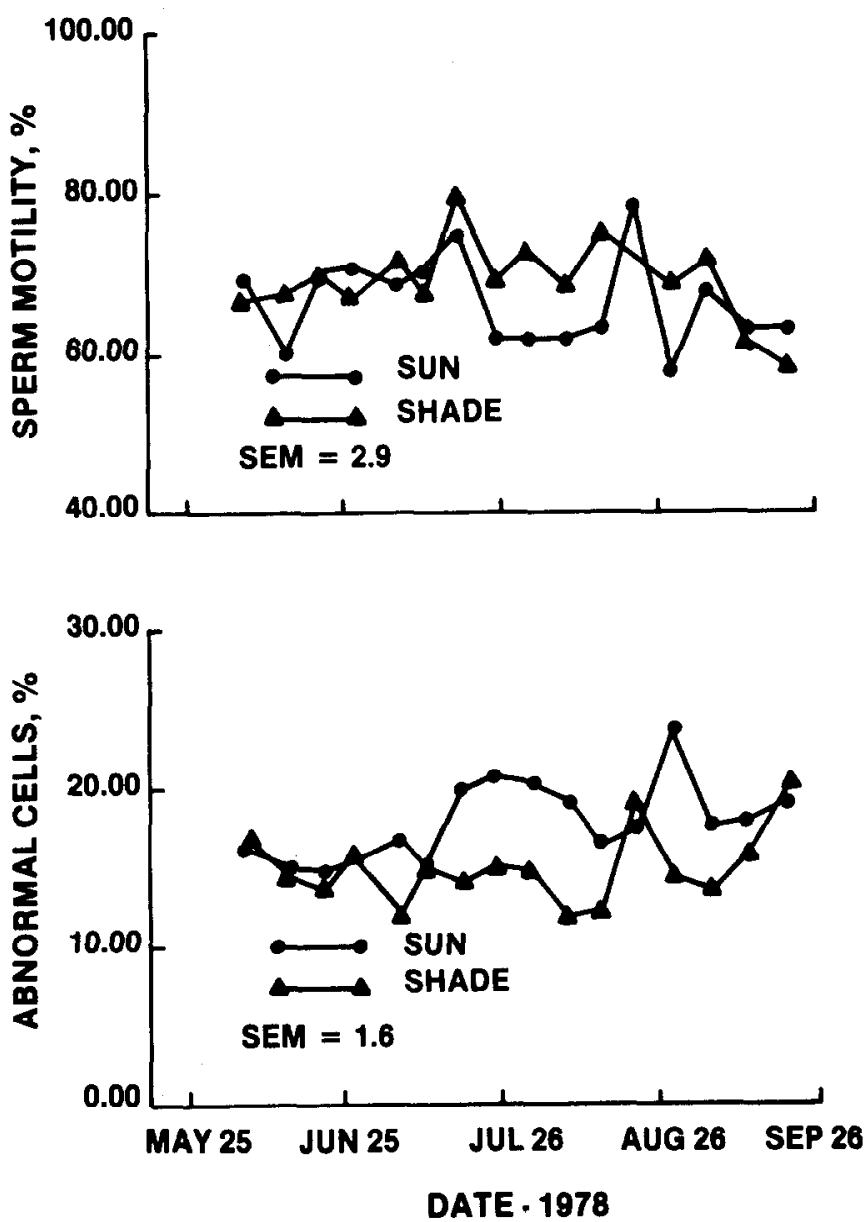

Fig. 4. Weekly changes in semen motility and percentage of abnormal cells during 1978. SEM is the standard error of the mean. 
influenced by shade and it would appear that either all bulls were stressed or inherently produced semen inferior in quality to bulls used in 1977. The latter explanation has merit in that semen quality was low at the beginning of the summer even before temperatures exceeded recognized thermoneutral zones $\left(32^{\circ} \mathrm{C}\right)$. On the other hand, sperm numbers were higher in 1978 than in 1977 and were higher for bulls without benefit of shade. One indication of the benefit of shade that repeated in both years was the percentage of abnormal cells (Table 4). Bulls with access to shade produced 14-15\% abnormal cells, whereas those without shade produced $18-20 \%((P<.14)$.

It is difficult to conclude from these data whether spermatogenesis or sperm maturation was affected by heat stress. During the week of July $19-26,1977$, ambient temperature reached $38^{\circ} \mathrm{C}$ and blackbulb temperature exceeded $46^{\circ} \mathrm{C}$ on 2 consecutive weeks (Fig. 1). Two weeks later motility reached its lowest point (Fig. 3). Meyerhoffer et al. (1976) observed a 2-week lag from the initiation from heat stress to the appearance of decreased sperm motility. Similar, though less pronounced depressions were noted in 1978, also 2 weeks following elevated ambient (above $38^{\circ} \mathrm{C}$ ) and blackbulb temperature (above $45^{\circ} \mathrm{C}$ ) (Fig. 2 and 4). Another explanation of the depression in motility in 1977 could be that the low point came 7-8 weeks after June 14 when the blackbulb temperature first went above $45^{\circ} \mathrm{C}$ (Fig. 4 \& 5). Meyerhoeffer et al. (1976) have shown that if the stress continued for 8 weeks, sperm production and quality was reduced and that 8 weeks were required for recovery, substantiating that the spermatogenic cycle was approximately 8 weeks. Their work would suggest that both spermatogenesis and maturation were influenced by heat. Regardless of whether the damage occurs during spermatogenes is or sperm maturation, reduced fertility in bulls could be the ultimate result.

In conclusion it appears from these data that inexpensive shades can provide some protection for breeding bulls from extreme summer temperatures. Heat stress can be especially important if bulls are to be used for breeding during summer months.

\section{Literature Cited}

Bond, J., and R.E. McDowell. 1972. Reproductive performance and physiological responses of beef females as affected by a prolonged high environmental temperature. J. Anim. Sci. 35:820-829.

Cartwright, T.C. 1955. Responses of beef cattle to high ambient temperatures. J. Anim. Sci. 14:350-362.

Dutt, R.H., and E.C. Simpson. 1957. Environment, temperature and fertility of Southdown rams early in the breeding season. J. Anim. Sci. 16:136-143.

Gill, J.L., and H.D. Hafs. 1971. Analysis of repeated measurements of animals. J. Anim. Sci. 33:331-336.

Erb, R.E., and D.R. Waldo. 1952. Changes in fertility of dairy bulls in Northeast Washington. J. Dairy Sci. 35:245-249.

Kropp, J.R., J.W. Holloway, D.F. Stephens, L. Knori, R.D. Morrison, and R. Totusek. 1973. Range behavior of Hereford, Hereford $X$ Holstein and Holstein non-lactating heifers. J. Anim. Sci. 36:797-802.

Mcllvain, E.H., and M.C. Shoop. 1971. Shade for improving cattle gains and rangeland use. J. Range Manage. 24:181-184.

Meyerhoffer, D.C., R.P. Wettemann, M.E. Wells, and E.J. Turman. 1976. Effect of elevated ambient temperature on bulls. J. Anim. Sci. 43:297 (Abstract).

Pontif, J.E., W.A. Nipper, A.F. Loyacano, and H.J. Brand. 1974. Studies of winter shelter and summer shade and fans for beef cattle in Louisiana. La. Agr. Exp. Sta. Prog. Rep.

Stott, G.H. 1961. Female and breed associated with seasonal fertility variation in dairy cattle. J. Dairy Sci. 44:1698-1704.

Warwick, E.J., and J. Bond. 1966. Influence of environment on growth and reproduction of cattle. USDA-ARS Bul. 44-167.

Wells, M.E., O.A. Awa, C.G. Jay, and S.S. Fancy. 1971. Effect of sexual rest and frequency of ejaculation on sperm acrosomal morphology. $J$. Dairy Sci. 54:526-530.

Wettemann. R.P., M.E. Wells, I.T. Omtvedt, C.E. Pope, and E.J. Turman. 1976. Influence of elevated ambient temperature on reproductive performance of boars. J. Anim. Sci. 42:664-669. 